\title{
THE EFFECT OF PROTEASE ON PRODUCTIVE AND SLAUGHTER TRAITS IN BROILER CHICKENS
}

\author{
V. Dosković ${ }^{1}$, S. Bogosavljević-Bošković ${ }^{1}$, Z. Pavlovski ${ }^{2}$, B. Milošević ${ }^{3}$, \\ Z. Škrbićc ${ }^{2}$ S. Radonjac ${ }^{1}$, V. Petričević ${ }^{2}$ \\ ${ }^{1}$ Faculty of Agronomy, University of Kragujevac, Cara Dušana 34, 32000, Čačak, Republic of Serbia \\ ${ }^{2}$ Institute for Animal Husbandry, Autoput 16, P. Box 23, 11080, Belgrade-Zemun, Republic of Serbia \\ ${ }^{3}$ Faculty of Agriculture, University of Pristina, Kosovska Mitrovica-Zubin potok-Lešak, 38219 Lešak \\ Corresponding author: vladosko@ttc.kg.ac.rs \\ Original scientific paper
}

Abstract: Carcass conformation is a very important parameter in assessing the overall appearance and meatiness of broilers. This study evaluates the effect of protease supplemented to reduced protein diets on production traits, dressed carcass weight and conformation measures in fast-growing Cobb 500 and slow-growing Master Gris broilers over a fattening period of 49 days. At slaughter, the following measurements were taken: pre-slaughter body weight (BW), conventionally dressed carcass weight and abdominal fat weight. Following carcass dissection into primal cuts, absolute conformation values, including metatarsus length (ML), keel length $(\mathrm{KL})$, breast depth (BD), breast angle (BA) and thigh girth (TG), were determined. For carcass conformation evaluation purposes, index values of carcass conformation measures BW/ML, BW/KL, BW/BD and BW/TG were identified. Genotype and sex had a significant effect on dressed carcass weight and all conformation measures, whereas the effect of different protein levels in protease-supplemented diets was significant only in Master Gris, for metatarsus length and the following indices: $\mathrm{BW} / \mathrm{ML}, \mathrm{BW} / \mathrm{KL}$ and $\mathrm{BW} / \mathrm{TG}$.

Key word: broilers, productive traits, carcass weight, carcass conformation.

\section{Introduction}

Modern chicken meat production involves hybrids known for their excellent meat quality and use of diet formulations that can ensure high meat yields and optimum meat quality.

In the past decades, the goal of broiler industry has been to obtain improved broiler performance in a minimum of time. In order to enhance production traits, broilers should be fed diets that can satisfy all their nutrient requirements. In recent years, in order to achieve maximum nutritional quality of broiler meat, increasing attention has been paid to the use of slow-growing strains, 
reduction in stocking density, extension of fattening period and broiler welfare improvement.

One of the most important nutritional requirements for optimum animal performance is to ensure an adequate protein level in broiler diet (Bregendahl et al., 2002). Most proteins are obtained from plant-based raw materials. Plant-based proteins are inadequate for poultry, in terms of both the amount and ratio of certain amino acids, with their nutrient content showing frequent variations in crude protein concentration and amino acid composition (Thorpe and Beal, 2001); moreover, they often contain anti-nutritional factors such as trypsin inhibitors and lectins. The nutritive value of several major chicken feed ingredients can be improved through exogenous enzymes.

Effects of the use of enzyme combinations (amylase, xylanase, protease) in chicken diets have been studied extensively (Gracia et al., 2003; Onderci et al., 2006). Angel et al. (2011) and Maiorka et al. (2009), on the other hand, studied the effect of single dietary enzymes (protease) supplemented to broiler diets.

The overall appearance and meatiness of broilers primarily depend on body conformation which can be directly associated with the amount and distribution of muscles i.e. slaughter value and meatiness, which render its value more definite, since meat yield, particularly of thighs, drumsticks and breasts, is indeed the main goal of poultry production (Pavlovski et al., 2006).

The objective of this study was to evaluate the effect of reduced crude protein levels of protease-supplemented diets on the productive performance and body conformation of fast-growing Cobb 500 and slow-growing Master Gris broilers over a fattening period of 49 days.

\section{Materials and Methods}

Two broiler hybrids were used in the experiment: fast-growing Cobb 500 and slow-growing Master Gris. A total of 300 day-old Cobb 500 broilers were allocated to three groups-boxes each containing 100 birds at a stocking density of $10 \operatorname{birds} / \mathrm{m}^{2}$.

Slow-growing Mater Gris hybrid included 300 day-old broilers in three groups with 100 broilers each at the same density of $10 \mathrm{birds} / \mathrm{m}^{2}$. The broilers were randomly grouped, giving a random ratio of male to female birds across groups. Chicks had free access to water and feed, and a 24-h photo-schedule was applied. Ad libitum feeding was used.

\section{Dietary treatments}

A three-stage feeding-fattening program was used, including starter (0-21 days), grower (22-42 days) and finisher stages (42-63 days).

One group of broilers served as the control-C (fed normal nutrient levels, in accordance with broiler needs during certain fattening stages), and the other two groups 
were experimental groups -E-I and E-II (fed diets containing 4\% and 6\% lower crude protein levels and supplemented with $0.2 \%$ and $0.3 \%$ protease, respectively).

Broiler feeds were in powdered form. Feed ingredients (used across fattening stages and test groups) and chemical composition of feeds are presented in Table 1.

A protease preparation commercially called Ronozyme ProAct (produced by DSM, The Netherlands) was used in the fattening trial. Ronozyme ProAct is a preparation of serine protease produced by a genetically modified strain of Bacillus licheniformis. It is produced in solid and liquid forms and is intended for use as a feed additive in chickens for fattening at a recommended dose of $200 \mathrm{mg} \mathrm{kg}-1$.

Body weight (BW), feed intake (FI) and mortality were recorded at 7-day intervals throughout the fattening trial. The data obtained were used to calculate the average body weight gain (BWG) and feed conversion ratio (FCR) at the starter, grower and finisher stages, as well as over the whole fattening period.

Table 1. Ingredients and nutrient composition of experimental diets for fattening chickens

\begin{tabular}{|l|c|c|c|c|c|c|c|c|c|}
\hline \multicolumn{1}{|c|}{ Ingredient, \% } & \multicolumn{3}{c|}{$\begin{array}{c}\text { Starter stage } \\
\text { (1 to 21 d) }\end{array}$} & \multicolumn{3}{c|}{$\begin{array}{c}\text { Grower stage } \\
\text { (22 to 42 d) }\end{array}$} & \multicolumn{3}{c|}{$\begin{array}{c}\text { Finisher stage } \\
\text { (43 to 49 d) }\end{array}$} \\
\hline \multicolumn{1}{|c|}{ Treatments } & C & E-1 & E-2 & C & E-1 & E-2 & C & E-1 & E-2 \\
\hline Maize & 52.49 & 54.92 & 56.26 & 63.15 & 65.28 & 66.34 & 68.62 & 70.60 & 71.59 \\
\hline Soybean meal & 22.24 & 19.79 & 18.44 & 13.00 & 10.85 & 9.78 & 9.10 & 7.10 & 6.10 \\
\hline Soybean groats & 18.50 & 18.50 & 18.50 & 17.00 & 17.00 & 17.00 & 15.40 & 15.40 & 15.40 \\
\hline Feeding yeast & 2.00 & 2.00 & 2.00 & 2.00 & 2.00 & 2.00 & 2.00 & 2.00 & 2.00 \\
\hline L-Lysine & 0.10 & 0.10 & 0.10 & 0.20 & 0.20 & 0.20 & 0.23 & 0.23 & 0.23 \\
\hline DL-Methionine & 0.22 & 0.22 & 0.22 & 0.30 & 0.30 & 0.30 & 0.30 & 0.30 & 0.30 \\
\hline Limestone & 1.10 & 1.10 & 1.10 & 1.10 & 1.10 & 1.10 & 1.10 & 1.10 & 1.10 \\
\hline Monocalcium phosphate & 1.30 & 1.30 & 1.30 & 1.20 & 1.20 & 1.20 & 1.20 & 1.20 & 1.20 \\
\hline Salt & 0.35 & 0.35 & 0.35 & 0.35 & 0.35 & 0.35 & 0.35 & 0.35 & 0.35 \\
\hline Calcium formiate & 0.40 & 0.40 & 0.40 & 0.40 & 0.40 & 0.40 & 0.40 & 0.40 & 0.40 \\
\hline Captex T & 0.30 & 0.30 & 0.30 & 0.30 & 0.30 & 0.30 & 0.30 & 0.30 & 0.30 \\
\hline Premix & 1 & 1 & 1 & 1 & 1 & 1 & 1 & 1 & 1 \\
\hline Protease & 0.00 & 0.20 & 0.30 & 0.00 & 0.20 & 0.30 & 0.00 & 0.20 & 0.30 \\
\hline Calculated composition & & & & & & & & & \\
\hline ME, kcal/kg & 3.081 & 3.100 & 3.112 & 3.157 & 3.174 & 3.183 & 3.181 & 3.198 & 3.207 \\
\hline Crude proteins, \% & 22.59 & 21.72 & 21.24 & 18.99 & 18.22 & 17.84 & 17.16 & 16.45 & 16.09 \\
\hline Crude fats, \% & 5.59 & 5.55 & 5.70 & 5.67 & 5.73 & 5.76 & 5.55 & 5.61 & 5.64 \\
\hline Ca, \% & 0.96 & 0.95 & 0.95 & 0.91 & 0.91 & 0.90 & 0.90 & 0.89 & 0.89 \\
\hline Total P, \% & 0.73 & 0.72 & 0.72 & 0.68 & 0.67 & 0.67 & 0.66 & 0.65 & 0.65 \\
\hline Available P, \% & 0.44 & 0.44 & 0.43 & 0.40 & 0.40 & 0,40 & 0.39 & 0.39 & 0.39 \\
\hline Total lysine, \% & 1.33 & 1.27 & 1.24 & 1.15 & 1.10 & 1.08 & 1.05 & 1.00 & 0.98 \\
\hline Methionine+cystine, \% & 0.92 & 0.90 & 0.89 & 0.91 & 0.89 & 0.88 & 0.86 & 0.84 & 0.83 \\
\hline
\end{tabular}

Treatments: C-control group, standard broiler diet, without protease; E-I- broilers fed a diet with a $4 \%$ reduction in crude protein level as compared to the control group, and $0.2 \%$ protease supplementation; E-II broilers fed a diet with a $6 \%$ reduction in crude protein level as compared to the control group, and $0.3 \%$ protease supplementation. 


\section{Data collection}

On day 49 of the fattening trial, 10 male and 10 female broilers were randomly selected from each group, tagged, weighed and slaughtered after a fasting period of 10 hours.

At slaughter, the following measurements were taken: conventionally dressed carcass weight and abdominal fat weight. Then, each carcass was individually dissected into primal cuts - breast, drumsticks, thighs, wings, back, pelvis (according to the Commission Regulation (EC) No. 543/2008).

On the slaughtering line, determined the absolute carcass conformation measures (by the method of Pavlovski and Mašić, 1983): breast angle-BA (degrees); metatarsus length-ML (mm); keel length-KL (mm); breast depth-BD(mm) and thigh girth-TG (mm).

Carcass conformation measures indicate the body structure and development of certain major carcass parts. In order to eliminate the effect of body weight (BW) on carcass conformation measures, their index values are presented: BW/ML, BW/KL, $\mathrm{BW} / \mathrm{BD}$ and $\mathrm{BW} / \mathrm{TG}(\mathrm{g} / \mathrm{mm})$ with the exception of breast angle, which is a genetically determined trait and, as such, under a low impact of body weight (Škrbić et al., 2011).

\section{Statistical analysis}

The data were subjected to conventional statistical methods. The significance of differences for production traits was tested by analysis of variance i.e. in a two-factor $2 \times 3$ design ( 2 hybrids and 3 feeding treatments).

The significance of differences for meat quality parameters (dressing percentages, percentage yields of primal cuts, and chemical composition of meat) was tested by analysis of variance i.e. in a three-factor $2 \times 3 \times 2$ design ( 2 hybrids, 3 feeding treatments and 2 sexes). The significant differences determined by analysis of variance and results of F-exp values were evaluated using Tukey's test. Significance was accepted at $\mathrm{P}<0.05$. The test parameters were subjected to an analysis of variance using $A N O V A$, Microsoft STATISTICA Ver. 5.0, StatSoft Inc. (1995).

\section{Results and Discussion}

The test broilers were fed throughout the three fattening stages, including starter, grower and finisher. The live performance of broilers (body weight-BW and feed conversion ratio-FCR) was monitored across starter, grower and finisher fattening stages, as presented in Table 2 . 
Table 2. Growth performance of broiler chickens fed different protease levels from 0-49 days

\begin{tabular}{|c|c|c|c|c|c|c|c|c|c|}
\hline \multicolumn{2}{|c|}{ Treatment } & \multicolumn{4}{|c|}{$\mathrm{BW}, \mathrm{g}$} & \multicolumn{4}{|c|}{ FCR } \\
\hline & & & Starter & Grower & Total & Starter & Grower & Finisher & Total \\
\hline Hybrid & Protease & $0 \mathrm{~d}$ & $21 d$ & $42 \mathrm{~d}$ & $49 \mathrm{~d}$ & 0 to $21 d$ & 22 to $42 d$ & 43 to $49 d$ & 1 to $49 d$ \\
\hline \multirow{3}{*}{$\begin{array}{l}\text { Cobb } \\
500\end{array}$} & No & $44.74^{\mathrm{a}}$ & $877.2^{\mathrm{a}}$ & $2629^{\mathrm{a}}$ & $2990^{\mathrm{a}}$ & $1.597^{\mathrm{b}}$ & $1.936^{\mathrm{b}}$ & 3.352 & $2.014^{\mathrm{b}}$ \\
\hline & $0.2 \%$ & $44.74^{\mathrm{a}}$ & $875.3^{\mathrm{a}}$ & $2601^{\mathrm{a}}$ & $2951^{\mathrm{ab}}$ & $1.562^{\mathrm{b}}$ & $1.914^{\mathrm{b}}$ & 3.283 & $1.978^{\mathrm{b}}$ \\
\hline & $0.3 \%$ & $44.77^{\mathrm{a}}$ & $860.6^{\mathrm{a}}$ & $2581^{\mathrm{a}}$ & $2872^{b}$ & $1.578^{\mathrm{b}}$ & $1.909^{b}$ & 3.766 & $2.005^{b}$ \\
\hline \multirow{3}{*}{$\begin{array}{l}\text { Master } \\
\text { Gris }\end{array}$} & No & $43.08^{b}$ & $688.5^{\mathrm{b}}$ & $2040^{b}$ & $2384^{c}$ & $1.923^{\mathrm{a}}$ & $2.324^{\mathrm{a}}$ & 3.452 & $2.380^{\mathrm{a}}$ \\
\hline & $0.2 \%$ & $42.96^{b}$ & $659.3^{\mathrm{c}}$ & $1973^{b}$ & $2340^{\mathrm{c}}$ & $2.031^{\mathrm{a}}$ & $2.309^{\mathrm{a}}$ & 3.244 & $2.384^{\mathrm{a}}$ \\
\hline & $0.3 \%$ & $43.00^{b}$ & $666.4^{b c}$ & $2014^{b}$ & $2376^{\mathrm{c}}$ & $2.009^{\mathrm{a}}$ & $2.175^{\mathrm{a}}$ & 3.224 & $2.293^{\mathrm{a}}$ \\
\hline \multicolumn{10}{|l|}{ p-value } \\
\hline \multicolumn{10}{|c|}{ Source of variation } \\
\hline \multicolumn{2}{|l|}{ Hybrid } & 0.001 & 0.001 & 0.001 & 0.001 & 0.011 & 0.014 & 0.497 & 0.009 \\
\hline \multicolumn{2}{|l|}{ Protease } & 0.891 & 0.048 & 0.174 & 0.129 & 0.770 & 0.379 & 0.677 & 0.601 \\
\hline
\end{tabular}

Table 2 shows that the body weight of Cobb 500 broilers was higher at the beginning of the fattening trial, on days 21 and 42 of age, and at the end of the trial on day $49(\mathrm{P}<0.01)$, as compared to Master Gris broilers. Also, different diets had no statistically significant effect on body weight $(\mathrm{P}>0.05)$, except at the end of the starter period $(21 \mathrm{~d})$, when a statistically significant difference between the experimental groups was determined in Master Gris broilers $(\mathrm{P}<0.05)$. Feed conversion ratio significantly differed $(\mathrm{P}<0.05)$ between the two hybrids at all fattening stages, except at the finisher stage, when both hybrids had a similar feed conversion ratio $(\mathrm{P}>0.05)$. Moreover, at the end of the fattening trial, fast-growing broilers exhibited superior feed conversion compared to slow-growing broilers $(\mathrm{P}<0.01)$. Protease supplementation did not have a significant effect on feed conversion $(\mathrm{P}>0.05)$.

Body weight and feed conversion ratio in Cobb 500 broilers were higher in this experiment than in studies by Café et al. (2002) and Abudabos (2010), but lower than in a study by Wang et al. (2007). Angel et al. (2011) and Maiorka et al. (2009) found that protease supplementation of broiler feeds, regardless of concentration, leads to weight gains similar to those in control broilers, and improves feed conversion ratio, as compared to control broilers (without protease).

Table 3 shows a significant difference between the hybrids in dressing percentage of conventionally dressed carcass $(\mathrm{P}<0.05)$. Pre-slaughter body weight was higher in Cobb 500 than in Master Gris, which was the most likely reason for the higher dressed carcass weight and, hence, the higher dressing percentage of conventionally dressed carcass in Cobb 500 broilers. In both hybrids, male broilers had a higher body weight but a lower dressing percentage as compared to females $(\mathrm{P}<0.01)$ 
Table 3. Values of yield conventionally dressed carcass, abdominal fat content in broiler carcass and broiler carcass conformation (index values) in test broilers across experimental groups

\begin{tabular}{|c|c|c|c|c|c|c|c|c|}
\hline \multicolumn{3}{|c|}{ Treatment } & \multirow{2}{*}{$\begin{array}{c}\text { Yield } \\
\text { “CP”,\% }\end{array}$} & \multirow{2}{*}{$\begin{array}{c}\text { Share of } \\
\text { AF,\%BM }\end{array}$} & \multirow{2}{*}{$\begin{array}{c}\mathrm{BM} / \mathrm{ML}, \\
\mathrm{g} / \mathrm{mm}\end{array}$} & \multirow{2}{*}{$\begin{array}{c}\mathrm{BM} / \mathrm{KL} \\
\mathrm{g} / \mathrm{mm}\end{array}$} & \multirow{2}{*}{$\begin{array}{c}\mathrm{BM} / \mathrm{BD}, \\
\mathrm{g} / \mathrm{mm}\end{array}$} & \multirow{2}{*}{$\begin{array}{c}\mathrm{BM} / \mathrm{TG}, \\
\mathrm{g} / \mathrm{mm}\end{array}$} \\
\hline Hybrid & $\begin{array}{c}\text { Prote } \\
\text { ase }\end{array}$ & Sex & & & & & & \\
\hline \multirow{6}{*}{$\begin{array}{l}\text { Cobb } \\
500\end{array}$} & \multirow[t]{2}{*}{ No } & $\hat{\sigma}$ & $86.23^{\mathrm{ab}}$ & $1.44^{\mathrm{b}}$ & $41.7^{\mathrm{a}}$ & $28.1^{\mathrm{a}}$ & $30.4^{\mathrm{a}}$ & $20.9^{\mathrm{a}}$ \\
\hline & & 웅 & $86.92^{\mathrm{ab}}$ & $1.70^{\mathrm{ab}}$ & $39.0^{\mathrm{abc}}$ & $24.7^{\mathrm{b}}$ & $26.9^{\mathrm{bc}}$ & $19.5^{\mathrm{b}}$ \\
\hline & \multirow[t]{2}{*}{$0.2 \%$} & $\frac{1}{0}$ & $85.92^{\mathrm{ab}}$ & $1.69^{\mathrm{ab}}$ & $41.7^{\mathrm{a}}$ & $28.0^{\mathrm{a}}$ & $30.0^{\mathrm{a}}$ & $21.7^{\mathrm{a}}$ \\
\hline & & $q$ & $87.53^{\mathrm{a}}$ & $1.74^{\mathrm{ab}}$ & $38.4^{\mathrm{bc}}$ & $24.7^{\mathrm{b}}$ & $27.4^{\mathrm{b}}$ & $19.1^{\mathrm{bc}}$ \\
\hline & \multirow[t]{2}{*}{$0.3 \%$} & $\hat{0}$ & $85.85^{\mathrm{ab}}$ & $1.45^{\mathrm{b}}$ & $39.9^{\mathrm{abc}}$ & $27.3^{\mathrm{a}}$ & $29.9^{\mathrm{a}}$ & $21.0^{\mathrm{a}}$ \\
\hline & & q & $86.71^{\mathrm{ab}}$ & $1.71^{\mathrm{ab}}$ & $37.3^{\mathrm{c}}$ & $24.0^{\mathrm{bc}}$ & $26.8^{\mathrm{bc}}$ & $18.7^{\mathrm{bc}}$ \\
\hline \multirow{6}{*}{$\begin{array}{l}\text { Master } \\
\text { Gris }\end{array}$} & \multirow[t]{2}{*}{ No } & $\hat{0}$ & $85.59^{b}$ & $1.41^{\mathrm{b}}$ & $33.5^{\mathrm{d}}$ & $22.7^{\mathrm{cd}}$ & $26.6^{\mathrm{bc}}$ & $18.5^{\mathrm{bc}}$ \\
\hline & & q & $85.69^{b}$ & $2.00^{\mathrm{ab}}$ & $31.7^{\mathrm{de}}$ & $21.1^{\mathrm{de}}$ & $24.1^{\mathrm{de}}$ & $16.8^{\mathrm{e}}$ \\
\hline & \multirow[t]{2}{*}{$0.2 \%$} & $\hat{0}$ & $86.68^{\mathrm{ab}}$ & $1.41^{\mathrm{b}}$ & $31.4^{\mathrm{de}}$ & $21.6^{\mathrm{de}}$ & $25.1^{\mathrm{cde}}$ & $17.0^{\mathrm{de}}$ \\
\hline & & q & $86.69^{\mathrm{ab}}$ & $1.94^{\mathrm{ab}}$ & $30.0^{\mathrm{e}}$ & $20.0^{\mathrm{e}}$ & $23.9^{\mathrm{de}}$ & $15.7^{\mathrm{e}}$ \\
\hline & \multirow[t]{2}{*}{$0.3 \%$} & $0^{1}$ & $85.49^{b}$ & $1.44^{\mathrm{b}}$ & $31.4^{\mathrm{de}}$ & $22.5^{\mathrm{cd}}$ & $25.6^{\mathrm{bcd}}$ & $18.2^{\mathrm{cd}}$ \\
\hline & & q & $86.17^{\mathrm{ab}}$ & $2.29^{\mathrm{a}}$ & $29.3^{\mathrm{e}}$ & $20.4^{\mathrm{e}}$ & $23.4^{\mathrm{e}}$ & $16.4^{\mathrm{e}}$ \\
\hline \multicolumn{9}{|c|}{ p-value } \\
\hline \multicolumn{9}{|c|}{ Source of variation } \\
\hline \multicolumn{3}{|c|}{ Hybrid } & 0.034 & 0.117 & 0.001 & 0.001 & 0.001 & 0.001 \\
\hline \multicolumn{3}{|c|}{ Protease } & 0.053 & 0.692 & 0.011 & 0.036 & 0.173 & 0.003 \\
\hline \multicolumn{3}{|c|}{ Sex } & 0.004 & 0.001 & 0.001 & 0.001 & 0.001 & 0.001 \\
\hline \multicolumn{3}{|c|}{ Hybrid $\mathrm{x}$ protease } & 0.252 & 0.256 & 0.329 & 0.030 & 0.396 & 0.001 \\
\hline \multicolumn{3}{|c|}{ Hybrid x sex } & 0.077 & 0.004 & 0.188 & 0.001 & 0.037 & 0.211 \\
\hline \multicolumn{3}{|c|}{ Protease $\mathrm{x}$ sex } & 0.699 & 0.395 & 0.975 & 0.931 & 0.209 & 0.433 \\
\hline \multicolumn{3}{|c|}{ Hybrid $\mathrm{x}$ protease $\mathrm{x}$ sex } & 0.386 & 0.811 & 0.857 & 0.894 & 0.906 & 0.333 \\
\hline
\end{tabular}

CP- "conventional processing", AF- abdominal fat, BM - pre-slaughter body mass, ML - Metatarsus length, $\mathrm{KL}$ - Keel length, BD - Breast depth, TG - Thigh girth

${ }^{\mathrm{a}-\mathrm{e}}$ Means within a column with different superscripts differ significantly $(\mathrm{P}<0.05)$.

The use of different protein levels and enzyme supplementation in broiler diet showed no statistical significance $(\mathrm{P}>0.05)$ in dressing percentage of conventionally dressed carcass and percentage of abdominal fat between the experimental groups. Pre-slaughter abdominal fat percentage were only affected by genotype $(\mathrm{P}<0.01)$ and sex $(\mathrm{P}<0.01)$, respectively. Somewhat lower values for the dressing percentage and abdominal fat content in Cobb 500 hybrid were reported by Petričević et al. (2011) (84.3\% and 1.3\%, respectively) and Blagojević et al. (2009) in Master Gris (dressing percentage of conventionally dressed carcass $83.68 \%$, abdominal fat content 3.16\%), whereas Abudabos (2010) reported an abdominal fat content of $2.43 \%$ in Cobb 500 on day 49 .

Master Gris hybrids had a higher metatarsus length $(\mathrm{P}<0.05)$ as compared to fast-growing Cobb 500. The other absolute conformation measures (keel length, breast depth, breast angle and thigh girth) were significantly higher in Cobb 500 broilers $(\mathrm{P}<0.01)$. Sex differences in both hybrids were statistically significant $(\mathrm{P}<0.01)$, with males having higher absolute conformation measures and better 
conformation scores, as consistent with the results of Pavlovski et al. (2007). Hopić et al. (2000) found significant differences in metatarsus length and breast angle between male and female broilers of several different genotypes. The high difference in body weight between males and females contributed to the significantly higher absolute and relative conformation scores in males than in females. Moreover, Blagojević et al. (2009) observed a significant $(\mathrm{P}<0.01)$ effect of hybrid and sex on absolute conformation measures.

The higher metatarsus length in slow-growing Master Gris suggests that this hybrid has been selected for prolonged feeding i.e. longer feeding as compared to fast-growing hybrids.

Index values i.e. relative body conformation measures were significantly higher in Cobb 500 broilers than in Master Gris $(\mathrm{P}<0.01)$, most likely due to the higher preslaughter body weight of Cobb 500 broilers. Similar results were obtained by Pavlovski et al. (2007), in their comparison between fast-growing Arbor Acres and mediumgrowing Redbro broilers, as well as by Blagojević et al. (2009) who compared two slow-growing genotypes (Master Gris and Farm Q), a fast-growing genotype (Hubbard Classic) and a medium-growing genotype (Redbro). Somewhat lower index values of conformation measures in Cobb 500 broilers were reported by Petričević et al. (2011).

Different protein levels in the protease-supplemented diet induced statistically significant differences $(\mathrm{P}<0.05)$ in Master Gris broilers in BW/ML index values between the control (without protease) and broilers fed $0.3 \%$ protease, as well as in $\mathrm{BW} / \mathrm{KL}$ between the control and broilers receiving $0.2 \%$ protease. Furthermore, the effect of protease was statistically significant $(\mathrm{P}<0.01)$ for BW/TG in Master Gris between the control and broilers fed $0.2 \%$ protease, and between broilers receiving diets supplemented with $0.2 \%$ and $0.3 \%$ protease. There was no statistically significant difference $(\mathrm{P}>0.05)$ in BW/BD index in both hybrids fed the test diets. Statistical significance was also observed between male and female carcasses. In both hybrids, males had significantly $(\mathrm{P}<0.01)$ higher relative conformation measures. In contrast, Blagojević (2011) found that the effect of sex on carcass conformation index values was non-significant for BW/KL, BW/BD and BW/TG, but significant for BW/ML.

\section{Conclusion}

The parameters analyzed suggest the following:

- Cobb 500 broilers had a higher body weight on days 21, 42 and 49 as compared to Master Gris $(\mathrm{P}<0.01)$. Different diets had no statistically significant effect on body weight, except at the end of the starter period in Master Gris broilers $(\mathrm{P}<0.05)$. Master Gris had a lower feed conversion ratio at all feeding stages as compared to Cobb $500(\mathrm{P}<0.01)$, with no differences being observed in feed conversion ratio resulting from the effect of different diets $(\mathrm{P}>0.05)$. 
- At the end of the feeding trial, on day 49 , at slaughter, fast-growing Cobb 500 broilers had higher values for the dressing percentage of conventionally dressed carcass $(\mathrm{P}<0.05)$, as compared to Master Gris.

- Based on the conformation measures (metatarsus length, keel length, breast depth, breast angle and thigh girth), carcass conformation scores were higher in Cobb 500.

- The reduction in crude protein level (by $4 \%$ and $6 \%$ ), along with protease supplementation $(0.2 \%$ and $0.3 \%)$ had no significant effect on dressing percentage of conventionally dressed carcass and abdominal fat content ( $\mathrm{P}>0.05)$. In Cobb 500 broilers, the effect of the test diets showed no difference in carcass conformation measures, but a significant difference was observed in metatarsus length in Master Gris. Moreover, in Master Gris broilers, there was a statistical difference in $\mathrm{BW} / \mathrm{ML}, \mathrm{BW} / \mathrm{KL}$ and BW/TG index values, but no difference in BW/BD.

- Sex had a significant effect on dressing percentage of conventionally dressed carcass, abdominal fat content, conformation measures and conformation indices $(\mathrm{P}<0.01)$.

The production traits, the dressing percentage of conventionally dressed carcass and carcass conformation measures were not affected by the diets used in this study. Therefore, the use of protease supplementation can be recommended (at a concentration of $0.2 \%$ or $0.3 \%$ ) in broiler diets with a $4 \%$ or $6 \%$ reduced crude protein level.

\section{Acknowledgments}

This study is part of the Project No. 31033 titled "Sustainable Conventional and Revitalized Traditional Production of Value-Added Poultry Meat and Eggs" funded by the Ministry of Science and Technological Development of the Republic of Serbia.

\section{Efekat proteaze na proizvodne i klanične osobine tovnih pilića}

V. Dosković, S. Bogosavljević-Bošković, Z. Pavlovski, B. Milošević, Z. Škrbić, S. Radonjac, V. Petričević

\section{Rezime}

Konformacija trupova pilića predstavlja vrlo važan parametar za ocenu opšteg izgleda i mesnatosti pilića. U radu je analiziran efekat enzima proteaze, uz snižen nivo sirovih proteina, na proizvodne osobine, masu obrađenog trupa i mere konformacije kod brzorastućeg-Cobb 500 i spororastućeg hibrida - Master Gris. Tov pilića trajao je 49 dana. Na liniji klanja izmerena je telesna masa pilića pre klanja, masa klasično-obrađenog trupa i masa abdominalne masti. Nakon rasecanja trupova na osnovne delove izmerene su apsolutne mere konformacije: dužina piska, dužina 
kobilice, dubina grudi, grudni ugao i obim bataka. Za bolju ocenu konformacije trupova izračunati su indeksi mera konformacije: telesna masa/dužina piska, telesna masa/dužina kobilice, telesna masa/dubina grudi i telesna masa/obim bataka.

Značajan je bio uticaj genotipa i pola na masu obrađenih trupova i sve ispitivane mere konformacije, dok je uticaj različitih nivoa proteina, uz dodatak enzima proteaze, bio značajan samo kod hibrida Master Gris, i to za dužinu piska i indekse telesna masa/dužina piska, telesna masa/dužina kobilice i telesna masa/obim bataka.

\section{References}

ABUDABOS A. (2010): Enzyme Supplementation of Corn-Soybean Meal Diets Improves Performance in Broiler Chicken. International Journal of Poultry Science, 9 (3), 292-297.

ANGEL C.R., SAYLOR W., VIEIRA S.L., WARD N. (2011): Effects of a monocomponent protease on performance and protein utilization in 7- to 22-day-old broiler chickens. Poultry Science, 90, 2281-2286.

BLAGOJEVIĆ M. (2011): Uticaj genotipa na intenzitet porasta i kvalitet trupa i mesa brojlerskih pilića u ekstenzivnom sistemu gajenja. Doktorska disertacija. Univerzitet u Novom Sadu, Poljoprivredni fakultet, Novi Sad, 1-116.

BLAGOJEVIĆ M., PAVLOVSKI Z., ŠKRBIĆ Z., LUKIĆ M., MILOŠEVIĆ N., PERIĆ L. (2009): The effect of genotype of broiler chickens on carcass quality in extensive rearing system. Acta veterinaria (Beograd), 59(1), 91-97.

BREGENDAHL K, SELL J.L., ZIMMERMAN D.R. (2002): Effect of low-protein diets on growth performance and body composition of broiler chicks. Poultry Science, 81, 1156-1167. CAFÉ M.B., BORGES C.A., FRITTS C.A., WALDROUP P.W. (2002): Avizyme Improves Performance of Broilers Fed Corn-Soybean Meal-Based Diets. Journal of Applied Poultry Research, 11, 29-33.

COMMISSION REGULATION (EC) No 543/2008. OJ L 157/46, 17.6.2008.

DOURADO L.R.B., SAKOMURA N.K., BARBOSA N.A.A., BONATO M.A., KAWUAUCHI I.M., FERNANDES J.B.K., COSTA F.G.P. (2009): Corn and Soybean Meal Metabolizable Energy with the Addition of Exogenous Enzymes for Poultry. Brazilian Journal of Poultry Science, Jan-Mar 11(1):51 - 55.

GRACIA M.I., ARANIBAR M.J., LAZARO R., MEDEL P., MATEOS G.G. (2003): Alpha-amylase supplementation of broiler diets based on corn. Poultry Science, 82, 436-442. HOPIĆ S., VIDOVIĆ V., MILOŠEVIĆ N., SUPIĆ B., PAVLOVSKI Z. (2000): Uticaj genotipa i godine na klanične osobine tovnih pilića. Biotecnology in Animal Husbandry, 17 (5-6), 47-53.

MAIORKA A., FAVERO A., MEURER R.F.P., MORAES M.T.T., SORBARA J.O.B. (2009): Broiler chicken performance and ileal digestibility is improved by a protease used in corn/soybean meal/meat bone meal diet. Abstracts 2009 
International Poultry Scientific Forum, Georgia World Congress Center, Atlanta, Georgia.T102, 33.

ONDERCI M., SAHIN N., SAHIN K., CIKIM G., AYDIN A., OZERCAN I., AYDIN S. (2006): Efficacy of supplementation of $\alpha$-amylase-producing bacterial culture on the performance, nutrient use, and gut morphology of broiler chickens fed a corn-based diet. Poultry Science, 85, 505-510.

PAVLOVSKI Z., MASIC B. (1983): Konformacija trupova pilica. VII Jug. savet. o problemima kvaliteta mesa i standardizacije, Bled, Zbornik referata, 115-125.

PAVLOVSKI Z., LUKIĆ M., CMILJANIĆ R., ŠKRBIĆ Z. (2006): Konformacija trupova pilića. Biotechnology in Animal Husbandry, 22 (3-4), 83-96.

PAVLOVSKI Z., ŠKRBIĆ Z., CMILJANIĆ R., LUKIĆ M., TOMAŠEVIĆ D. (2007): Uticaj sistema gajenja i bioloških faktora na konformaciju trupa i klanične osobine pilića u tovu. Biotechnology in Animal Husbandry, 23 (3-4), 59-66.

PETRIČEVIĆ V., PAVLOVSKI Z., ŠKRBIĆ Z., LUKIĆ M. (2011): The effect of genotype on production and slaughter properties of broiler chickens. Biotechnology in Animal Husbandry, 27 (2), 171-181.

STATSOFT INC. STATISTICA FOR WINDOWS (1995): Version 6.0, Computer program manual. Tulsa: StatSoft Jnc.

ŠKRBIĆ Z., PAVLOVSKI Z., LUKIĆ M., MILIĆ D. (2011): The effect of rearing conditions on carcass slaughter quality of broilers from intensive production. African Journal of Biotechnology 10(10), 1945-1952.

THORPE J., BEAL J.D. (2001): Vegetable Protein Meals and the Effects of Enzymes. Pages 125-143 in: M.R. Bedford and G.G. Partridge, Ed. Enzymes in Farm Animal Nutrition. CABI Publishing, Wallingford, Oxford, UK.

WANG Z., CERRATE S., COTO C., YAN F., WALDROUP P.W. (2007): Utilization of Distillers Dried Grains with Solubles (DDGS) in Broiler Diets Using a Standardized Nutrient Matrix. International Journal of Poultry Science, 6 (7), 470-477. 